\title{
PIROLISIS PELEPAH KELAPA SAWIT UNTUK MENGHASILKAN FENOL PADA ASAP CAIR
}

\section{PALM MIDRIB PYROLYSIS TO PRODUCE PHENOL IN LIQUID SMOKE}

\author{
Seri Maulina, Nurtahara, Fakhradila* \\ Departemen Teknik Kimia, Fakultas Teknik, Universitas Sumatera Utara \\ Jl. Almamater Kampus USU, Medan, 20155, Indonesia \\ *Email: fakhradila@gmail.com
}

\begin{abstract}
Abstrak
Pelepah kelapa sawit merupakan limbah di perkebunan kelapa sawit yang mengandung senyawa selulosa, hemiselulosa dan lignin. Pirolisis pelepah kelapa sawit akan menghasilkan fenol yang berasal dari lignin. Tujuan dari penelitian ini adalah untuk mendapatkan senyawa fenol sebagai fungsi dari waktu dan suhu. Proses pirolisis dilakukan pada suhu $200{ }^{\circ} \mathrm{C}, 300{ }^{\circ} \mathrm{C}, 400{ }^{\circ} \mathrm{C}, 500{ }^{\circ} \mathrm{C}$ dan $600{ }^{\circ} \mathrm{C}$ dengan variasi waktu pirolisis 30 menit, 60 menit dan 90 menit. Analisa dilakukan dengan menggunakan Spektrofotometer UV-Visible. Dari penelitian diketahui bahwa kadar senyawa fenol dalam asap cair meningkat seiring dengaan naiknya suhu dan waktu pirolisis. Kadar total fenol asap cair tertinggi diperoleh pada suhu pirolisis $600^{\circ} \mathrm{C}$ selama 90 menit, yaitu sebesar $17,966 \%$.
\end{abstract}

Kata Kunci : pelepah kelapa sawit, fenol, asap cair, kandungan fenolik

\begin{abstract}
Palm midrib is a waste in oil palm plantations that containing cellulose, hemicellulose and lignin compounds. Palm midrib pyrolysis will produce phenol derived from lignin. The purpose of this study was to obtain phenol compounds as a function of time and temperature. The pyrolysis process was carried out at $200{ }^{\circ} \mathrm{C}, 300{ }^{\circ} \mathrm{C}, 400{ }^{\circ} \mathrm{C}, 500{ }^{\circ} \mathrm{C}$ and $600{ }^{\circ} \mathrm{C}$ with variation of pyrolysis time of 30 minutes, 60 minutes and 90 minutes. The analysis was performed using UV-Visible Spectrophotometer. The content of phenol compounds in liquid smoke increases with the rise of temperature and pyrolysis time. The highest total phenol content in liquid smoke was obtained at $600{ }^{\circ} \mathrm{C}$ for 90 minutes pyrolysis, which was $17.966 \%$.
\end{abstract}

Keywords : palm midrib, phenol, liquid smoke, phenolic compound

\section{Pendahuluan}

Pelepah kelapa sawit merupakan limbah padat yang berasal dari perkebunan kelapa sawit. Pada saat panen tandan buah segar, 1-2 helai pelepah kelapa sawit dipotong dengan tujuan memperlancar penyerbukan dan mempermudah panen berikutnya. Jumlah pelepah kelapa sawit yang telah berproduksi dapat mencapai $40-50$ pelepah/pohon/tahun dengan bobot pelepah sebesar 4,5 kg berat kering per pelepah. Dalam satu hektar perkebunan kelapa sawit diperkirakan dapat menghasilkan 6,3 ton pelepah per tahun. Pelepah kelapa sawit termasuk kategori limbah basah (wet by-product) karena masih mengandung kadar air sekitar 75\%, sehingga dapat rusak dengan cepat apabila tidak segera diproses [18].

Pelepah kelapa sawit terdiri dari komponen lignoselulosa, seperti selulosa sebesar $34,89 \%$, hemiselulosa sebesar $27,14 \%$ dan lignin sebesar 19,87\% serta zat-zat ekstraktif [11, 13]. Dengan komposisi tersebut dan dengan jumlah pelepah yang dihasilkan cukup banyak, maka limbah pelepah sawit memiliki potensi yang besar untuk dimanfaatkan sebagai bahan baku pembuatan asap cair yang memiliki nilai ekonomis lebih tinggi.

Asap cair dapat diproduksi dengan metode pirolisis biomasa dan salah satu senyawa yang terkandung di dalamnya adalah senyawa fenolik dalam asap cairnya. Senyawa fenolik yang terkandung di dalam asap cair yaitu senyawa fenol, 2-methoxy fenol, 2,6-dimethoxy fenol, 1,2-benzenediol, 4 methyl catechol, dan 3methoxy-1,2-benzenediol $[4,5,7]$.

\section{Teori}

Pirolisis adalah proses dekomposisi termal yang terjadi tanpa kehadiran oksigen untuk mengkonversi biomassa menjadi arang padat, cair (bio-oil) dan gas. Pirolisis dianggap sebagai proses yang dapat digunakan dalam industri untuk mengkonversi biomassa [2, 17]. Setiap komponen dari lignoselulosa (selulosa, hemiselulosa dan lignin) biomassa dipirolisis pada tingkatan yang berbeda dengan mekanisme yang berbeda. Hasil analisis TGA menunjukkan pirolisis hemiselulosa dan selulosa berlangsung cepat dengan kehilangan berat paling banyak terjadi pada suhu $220-315{ }^{\circ} \mathrm{C}$ dan $315-400{ }^{\circ} \mathrm{C}$. Lignin paling sulit terdekomposisi dan 
kehilangan berat terjadi pada rentang suhu yang panjang yaitu $160-900{ }^{\circ} \mathrm{C}$ [8]. Lignin terurai pada rentang temperatur yang lebih luas dibandingkan dengan selulosa dan hemiselulosa yang cepat terdegradasi dalam rentang suhu yang sempit. Karena terdapat kestabilan termal jelas dari lignin selama pirolisis [24].

Komponen-komponen penyusun asap cair terdiri dari asam (2,8\% hingga 9,5\%), karbonil $(2,6 \%$ hingga $4,0 \%)$, dan senyawa fenolik $(0,2$ $\%$ hingga $2,9 \%)$. Terdapat juga air (11\% hingga $92 \%)$, tar (1\% hingga $7 \%$ ) serta senyawa hidrokarbon polisiklis aromatis (HPA) seperti benzopiren yang berbahaya bagi kesehatan karena bersifat karsinogen. Komponen asap cair sangat bervariasi tergantung jenis kayu, umur, iklim dan jenis tanah [16].

Kandungan fenol dan turunannya pada asap cair dipengaruhi oleh kandungan lignin dan temperatur pirolisis. Senyawa fenol dapat memperpanjang masa simpan produk asapan, disamping itu fenol memberikan cita rasa dan warna yang khas pada produk olahan [1, 15]. Fenol merupakan unsur aktif yang memberikan efek sebagai antibakteri dan antimikroba pada asap cair. Senyawa ini berperan sebagai pemberi rasa dan antioksidan. Kandungan fenol yang tinggi memberikan indikasi yang sangat baik bahwa asap cair dapat digunakan sebagai bahan pengawet dan menghambat kerusakan yang disebabkan oleh oksidasi lemak. Kualitas fenol pada kayu sangat bervariasi yaitu antara 10-200 $\mathrm{mg} / \mathrm{kg}[19,25]$.

\section{Metodologi Penelitian}

Analisis Kadar Hemiselulosa, Selulosa dan Lignin Pelepah Kelapa Sawit

Satu gram sampel kering (berat a) ditambahkan $150 \mathrm{~mL} \mathrm{H}_{2} \mathrm{O}$ dan direfluk pada suhu $100{ }^{\circ} \mathrm{C}$ dengan water bath selama 1 jam. Hasilnya disaring, residu dicuci dengan air panas $300 \mathrm{~mL}$. Residu kemudian dikeringkan dengan oven sampai beratnya konstan dan kemudian ditimbang (berat b). Residu ditambah $150 \mathrm{~mL}$ $\mathrm{H}_{2} \mathrm{SO}_{4} 1 \mathrm{~N}$, kemudian direfluk dengan water bath selama 1 jam pada suhu $100{ }^{\circ} \mathrm{C}$. Hasilnya disaring dan dicuci sampai netral $(300 \mathrm{~mL})$ dan residunya dikeringkan hingga beratnya konstan. Berat ditimbang (berat c). Residu kering ditambahkan $100 \mathrm{~mL} \mathrm{H}_{2} \mathrm{SO}_{4} 72 \%$ dan direndam pada suhu kamar selama 4 jam. Ditambahkan $150 \mathrm{~mL} \mathrm{H}_{2} \mathrm{SO}_{4} 1 \mathrm{~N}$ dan direfluk pada suhu 100 ${ }^{\circ} \mathrm{C}$ dengan water bath selama 1 jam pada pendingin balik. Residu disaring dan dicuci dengan $\mathrm{H}_{2} \mathrm{O}$ sampai netral $(400 \mathrm{~mL})$. Residu kemudian dipanaskan dengan oven dengan suhu $100{ }^{\circ} \mathrm{C}$ sampai beratnya konstant dan ditimbang (berat d). Selanjutnya residu diabukan dan ditimbang (berat e).

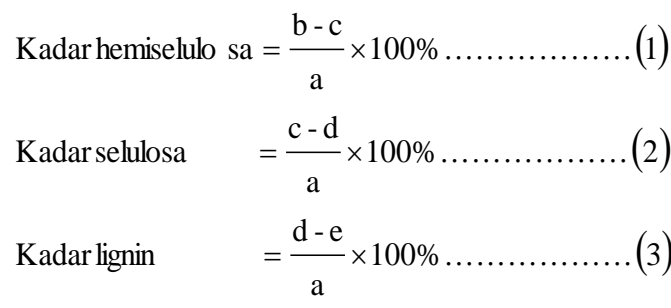

\section{Pembuatan Asap Cair}

Pelepah kelapa sawit yang digunakan sebagai bahan baku pada penelitian ini merupakan limbah pelepah kelapa sawit yang dipotong sebelum panen dilakukan. Pelepah tersebut diperkecil ukurannya hingga berbentuk cacahan. Pengecilan ukuran partikel bahan baku dapat meningkatkan laju pemanasan, sehingga waktu yang diperlukan untuk mendapatkan asap cair lebih singkat.Pembuatan asap cair dilaksanakan di Laboratorium Mekanik, Fakultas Teknik, Politeknik Negeri Medan. Sedangkan analisis kandungan fenol asap cair dilaksanakan di Laboratorium Ekologi, Fakultas Teknik, Universitas Sumatera Utara.

Alat yang digunakan untuk membuat asap cair yaitu rangkaian reaktor pirolisis. Sedangkan peralatan yang digunakan untuk analisis diantaranya adalah Spektrofotometer $U V$ Visible, neraca analitik, corong gelas, dan peralatan penunjang analisis lainnya.

Pelepah kelapa sawit terlebih dahulu diperkecil ukurannya kemudian dikeringkan dibawah sinar matahari langsung dan dengan bantuan pemanasan oven. Bahan baku yang digunakan untuk setiap proses pirolisis adalah 500 gram. Bahan baku di pirolisis pada suhu 200 ${ }^{\circ} \mathrm{C}, 300{ }^{\circ} \mathrm{C}, 400{ }^{\circ} \mathrm{C}, 500{ }^{\circ} \mathrm{C}$ dan $600{ }^{\circ} \mathrm{C}$ dengan waktu pirolisis 30 menit, 60 menit, dan 90 menit.

\section{Analisis Kuantitatif Kandungan Fenol}

Analisa kuantitatif total senyawa fenol dilakukan dengan metode folin-ciocalteu. Sebanyak $30 \mathrm{mg}$ sampel uji dilarutkan dalam 10 $\mathrm{ml}$ etanol. Sebanyak $0,5 \mathrm{ml}$ larutan sampel uji ditambahkan dengan $5 \mathrm{ml}$ perekasi folin cioceltaeu (1:10) dan $4 \mathrm{ml}$ natrium karbonat $1 \mathrm{M}$. Campuran dibiarkan selama 15 menit kemudian absorbansi diukur menggunakan spektrofotometer UV-Vis pada panjang gelombang $701 \mathrm{~nm}$. Pengukuran dilakukan sebanyak tiga kali. Fenol total dihitung dengan menggunakan persamaan regresi linear dari kurva kalibrasi asam galat yang telah diukur sebelumnya 
Hasil dan Pembahasan

Hasil Analisis Kadar Hemiselulosa, Selulosa dan Lignin Bahan Baku

Sebelum dilakukan proses pirolisis, terlebih dahulu ditentukan kandungan hemiselulosa, selulosa, dan lignin yang ada dalam pelepah kelapa sawit. Tujuannya adalah untuk mengetahui seberapa banyak komponen tersebut di dalam bahan baku sehingga nantinya dapat diketahui berapa banyak komponen yang terdekomposisi pada proses pirolisis. Hasil pengujian kandungan hemiselulosa, selulosa, dan lignin pada pelepah kelapa sawit dapat dilihat pada Tabel 1.

Tabel 1. Kandungan Hemiselulosa, Selulosa, dan Lignin pada Pelepah Kelapa Sawit

\begin{tabular}{|c|c|}
\hline Komponen & Kadar $(\boldsymbol{\%})$ \\
\hline Hemiselulosa & 28,43 \\
\hline Selulosa & 26,47 \\
\hline Lignin & 17,65 \\
\hline
\end{tabular}

Tabel 1 menunjukkan bahwa pelepah kelapa sawit berpotensi sebagai bahan baku pembuatan asap cair yang memiliki banyak manfaat melalui proses pirolisis karena mengandung kadar hemiselulosa, selulosa dan lignin yang cukup tinggi.

Dari Tabel 1 dapat dilihat adanya perbedaan persentase lignin dalam pelepah kelapa sawit. Hal ini dikarenakan lignin tidak tersebar secara merata pada keseluruhan kayu berdasarkan letak ketinggiannya. Kandungan lignin tertinggi terdapat pada bagian pangkal dan terendah terdapat pada bagian ujung kayu [20].

Berdasarkan penelitian sebelumnya bahwa pelepah kelapa sawit mengandung selulosa $31,7 \%$, hemiselulosa $33,9 \%$, dan lignin $17,4 \%$ [22]. Sedangkan kandungan pelepah kelapa sawit yang di peroleh dari penelitian ini mengandung selulosa 25,36\%, hemiselulosa $24,96 \%$ dan lignin $16,96 \%$. Perbedaan ini dapat disebabkan oleh berbagai faktor, diantaranya faktor umur tanam dan tempat tumbuh kelapa sawit. Proses pirolisis senyawa hemiselulosa, selulosa dan lignin akan menghasilkan asap cair yang sangat sesuai untuk proses lanjut. Pada proses pirolisis, komposisi produk akhir sangat bergantung pada kondisi bahan baku dan kondisi proses pirolisis [6].

Pirolisis lignin akan menghasilkan senyawa fenolik seperti fenol, guaiakol, siringol bersama dengan homolog dan derivatnya [10]. Senyawa asam yang ada didalam asap cair sebagian besar adalah asam asetat dan asam lainnya sehingga menyebabkan asap cair yang dihasilkan bersifat asam. Disamping itu kadar fenol juga mempengaruhi pH [19]. Besarnya lignin yang terkonversi akan meningkatkan kadar fenol asap cair sehingga kualitasnya sebagai pengawet menjadi lebih baik

\section{Analisis Kadar Total Fenol Asap Cair}

Senyawa fenol berperan sebagai antioksidan sehingga dapat memperpanjang masa simpan produk. Analisis kadar fenol asap cair dari cacahan pelepah kelapa sawit dilakukan menggunakan Spektrofotometer UV-Visible pada panjang gelombang $701 \mathrm{~nm}$. Panjang gelombang yang dipilih adalah panjang gelombang dengan absorbansi maksimal. Pengukuran yang dilakukan pada panjang gelombang yang maksimal akan menguntungkan karena dapat menghasilkan linearitas antara konsentrasi dan absorbansi pengukuran, memberikan sensitivitas pengukuran yang tinggi dan mengurangi kesalahan pada saat pengukuran ulang. Hasil analisis fenol dalam asap cair hasil pirolisis cacahan pelepah kelapa sawit dapat dilihat pada Gambar 1.

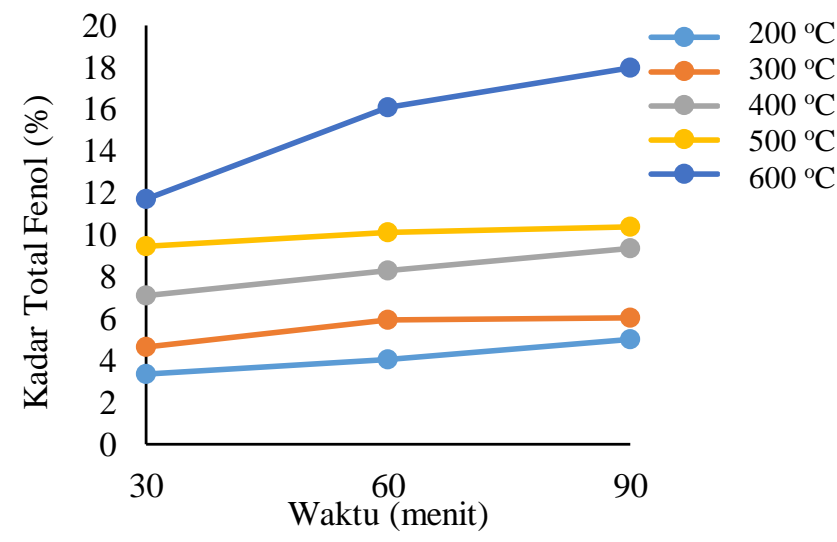

Gambar 1. Pengaruh Waktu dan Suhu Pirolisis terhadap Kadar Total Fenol Asap Cair

Gambar 1 menunjukkan nilai kadar total fenol asap cair yang dihasilkan dari pirolisis pelepah kelapa sawit. Kadar total fenol asap cair dipengaruhi oleh beberapa faktor diantaranya suhu dan waktu pirolisis.

Secara umum kadar total fenol akan meningkat dengan kenaikan suhu pada waktu pirolisis yang konstan. Demikian juga halnya dengan kenaikan waktu pada suhu pirolisis yang konstan. Penggunaan suhu tinggi pada proses pirolisis akan meningkatkan kandungan senyawa fenolik dalam asap cair [3]. Selain suhu, waktu pirolisis juga mempengaruhi kadar total fenol yang dihasilkan. Hal ini disebabkan semakin lama waktu pirolisis maka kontak antara panas 
dengan komponen penyusun bahan baku yang akan diuraikan akan lebih lama [7] sehingga semakin banyak komponen bahan baku, dalam hal ini lignin, yang teruraikan.

Namun dapat dilihat kurva pada suhu 600 ${ }^{\circ} \mathrm{C}$ terjadi peningkatan kadar total fenol yang signifikan. Kadar total fenol dalam asap cair dipengaruhi oleh kandungan lignin bahan dan suhu pirolisis. Lignin sangat stabil dan sukar terdekomposisi karena memiliki struktur yang kompleks sehingga baru akan terurai pada suhu tinggi [21]. Lignin terdekomposisi secara maksimal membentuk senyawa fenolik dan turunannya pada suhu $650{ }^{\circ} \mathrm{C}$ [9]. Selain itu pada suhu di atas $400{ }^{\circ} \mathrm{C}$, lignin mengalami proses pirolisis sekunder sehingga akan terbentuk senyawa fenol yang semakin banyak [12]. Kadar total fenol pada asap cair yang diperoleh dari penelitian sebelumnya dengan bahan baku tempurung nyamplung pada kondisi operasi 200$500{ }^{\circ} \mathrm{C}$ selama 5-7 jam yaitu berkisar antara $0,66-$ $4,19 \%$ [21]. Sedangkan kandungan kadar total fenol yang diperoleh dari penelitian ini berkisar antara 3,34-17,96\%.

Kadar total fenol asap cair yang diperoleh dari pirolisis pelepah kelapa sawit lebih banyak daripada kadar total fenol yang diperoleh dari pirolisis tempurung nyamplung. Hal ini dapat disebabkan oleh banyak faktor antara lain bahan baku yang digunakan lebih banyak. Faktor lainnya adalah temperatur pirolisis yang digunakan pada penelitian ini lebih optimal sehingga kandungan lignin pada bahan baku lebih efektif terurai secara sempurna.

Pirolisis lignin menyebabkan terdegradasinya makromolekul lignin sehingga terbentuk senyawa fenolik seperti fenol, 4-vinil fenol, 2-metoksi-4-vinil fenol, dan 2,6dimetoksi-fenol [14]. Jumlah fenol, methoxyphenols, dimethylphenols dan etilfenol relatif meningkat terhadap peningkatan suhu pembakaran selama pirolisis kayu. Degradasi termal lignin cukup penting karena menyebabkan pembentukan fenol seperti guaiakol (2-methoxyphenol) dan syringol (2,6-di methoxy phenol) dan ester fenolik, bersama dengan senyawa terkaitnya dari rantai samping metil, etil, propil, vinil, alil, dan propenil. Degradasi lignin selama pirolisis menyebabkan pembentukan turunan guaiakol, misalnya asam ferulic, atau turunan syringol, misalnya asam sinapik. Pirolisis awal lignin terjadi dengan pembelahan pada cincin furan dan pirena heterosiklik, dan ikatan eter dan kemudian menghasilkan guaiakol, yang selanjutnya dapat terdegradasi membentuk fenol dan kresols. Senyawa ini berfungsi sebagai perasa dan antioksidan pada asap cair [23].
Pada penelitian ini kadar total fenol asap cair tertinggi diperoleh pada suhu $600{ }^{\circ} \mathrm{C}$ dan waktu pirolisis selama 90 menit sebesar 17,966 $\%$. Sedangkan kadar total fenol asap cair terendah diperoleh pada suhu $200{ }^{\circ} \mathrm{C}$ dengan waktu pirolisis selama 30 menit sebesar 3,349\%.

\section{Kesimpulan}

Pelepah kelapa sawit memiliki kadar hemiselulosa, selulosa dan lignin sebesar 24,96; 25,36 dan $16,96 \%$. Suhu dan waktu pirolisis mempengaruhi kadar total fenol dalam asap cair yang diperoleh, dimana kenaikan suhu dan waktu akan meningkatkan kadar total fenol asap cair. Kadar total fenol tertinggi diperoleh pada suhu pirolisis $600{ }^{\circ} \mathrm{C}$ selama 90 menit, yaitu sebesar $17,966 \%$. Suhu pirolisis yang tinggi memberikan energi yang lebih besar untuk mendegradasi lignin dalam pelepah kelapa sawit dan waktu pirolisis yang semakin lama meningkatkan kontak antara panas dengan lignin sehingga meningkatkan kadar total fenol dalam asap cair.

\section{Daftar Pustaka}

[1] A. Akbar, R. Paindoman, P. Coniwati, Pengaruh Variabel Waktu dan Temperatur terhadap Pembuatan Asap Cair dari Limbah Kayu Pelawan (Cyanometra cauliflora), Jurnal Teknik Kimia (2013) No.1, Vol. 19.

[2] A. Demirbas. Biomass Resource Facilities and Biomass Conversion Processing for Fuels and Chemicals, Energy Convers Manage, 42 (2001).

[3] D. Ardilla, Tamrin, B. Wirjosentono, Eddyanto, dan M. S. Siregar, Determination of Phenol Content of Liquid Smoke of Palm Oil Shell: Characterization by Using Gas Chromatography- Mass Spectra and Fourier Transformed Infra Red, Chemistry and Material Research (2015) Vol. 7 No. 4, ISSN 2224-3224 (Print) ISSN 2225-0956 (Online).

[4] D. K. Essumang, D. K. Dodoo dan J. K. Adjei, Polycyclic Aromatic Hydrocarbon (PAH) Contamination in Smoke-Cured Fish Products, Jurnal of Food Composition and Analysis 27 (2012).

[5] E. Noor, C. Luditama dan G. Pari, Isolasi dan Pemurnian Asap Cair Berbahan Dasar Tempurung dan Sabut Kelapa secara Pirolisisdan Distilasi, Prosiding Konferensi Nasional Kelapa VIII, 2009.

[6] Fachrizal, Studi Pemanfaatan Gelombang Mikro pada Pengembangan Teknologi 
Pirolisis Biomassa, Jurnal Ilmiah Teknologi Energi (2013) Vol. 1 No. 16.

[7] F. Swastawati, T. W. Agustini, Y. Darmanto, dan E. N. Dewi, Liquid Smoke Performance Of Lamtoro Wood And Corn Cob. Journal of Coastal Development (2010), Vol. 10, No. 3, ISSN: 1410-5217.

[8] H. Yang, R. Yan, H. Chen, D. H. Lee dan C. Zheng, Characteristic Of Hemicellulose, Cellulose And Lignin Pyrolisis, Fuel 86 (2007).

[9] H. Zhang, R. Xiao, J. Nie, Catalytic Pyrolysis of Black-Liquor Lignin by Cofeeding with Different Plastics in a Fluidized Bed Reactor, Bioresour Technol $192 \quad$ (2015) doi:10.1016/j.biortech.2015.05.040.

[10] J. M. Lingbeck, P. Cordero, C. A. O'Bryan, M. G. Johnson, S. C. Ricke dan P. G. Crandall, Functionality Of Liquid Smoke As An All-natural Antimicrobial In Food Preservation, Meat Science 97 (2014).

[11] L. S. Hong, D. Ibrahim dan I. C. Omar, Oil Palm Frond for the Production of Bioethanol, International Journal of Biochemistry and Biotechnology (2012) Vol. 1 (1).

[12] T. Nakamura, H. Kawamoto, S. Saka, Pyrolysis Behavior of Japanese Cedar Wood Lignin Studied with Various Model Dimers, J Anal Appl Pyrolysis 81 (2008).

[13] Padil dan Yelmida, Produksi Nitroselulosa Sebagai Bahan Baku Propelan Yang Berbasis Limbah Padat Sawit, Laporan Penelitian Hibah Penelitian Stranas Batch II, Universitas Riau, 2009.

[14] P. R. Patwardhan, R. C. Brown, B. H. Shanks, Understanding the fast Pyrolysis of Lignin. Chemsuschem 4 (2011). doi:10.1002/cssc.201100133.

[15] R. Aiditra, B. Cahyono dan F. Swastawati, Identifikasi Komponen Penyusun Asap Cair dari Ampas Sagu dan Kulit Batang Tanaman Sagu (Metroxylon sagu Rottb) serta Penentuan Senyawa Fenolat Total dan Aktivitas Antioksidan, Chem Info (2013) Vol. 1, No. 1.

[16] Ratnawati dan S. Hartanto, Pengaruh Suhu Pirolisis Cangkang Sawit terhadap Kuantitas dan Kualitas Asap Cair, Jurnal Sains Materi Indonesi (2010) Vol. 12 (1), ISSN 1411 - 1098.

[17] R. Marsh, S. Hewlett, T. Griffiths and K. Williams, Advanced thermal treatment for solid waste - a waste manager's guide, Proceeding of the 22nd international conference on solid waste management and technology, Philadelphia, USA, 2007.

[18] R. Widiastuti dan D. K. Syahbana, Serat Pelepah Kelapa Sawit (SEPAWIT) Untuk Bahan Baku Produk Kerajinan, Prosiding Seminar Nasional $4^{\text {th }}$ UNS SME's Summit \& Awards "Sinergitas Pengembangan UMKM dalam Era Masyarakat Ekonomi ASEAN (MEA)', 2015.

[19] S. P. A. Anggraini dan S. Yuniningsih, Utilization Of Various Types Of Agricultural Waste Became Liquid Smoke Using Pyrolisis Process, Chemical and Process Engineering Research (2014) Vol. 28, ISSN : 2224-746.

[20] Supartini, Komponen Kimia Kayu Meranti Kuning (Shorea macrobalanos), Jurnal Penelitian DIPTEROKARPA (2009) Vol.3. No.1.

[21] S. Wibowo, Karakteristik Asap Cair Tempurung Nyamplung, Jurnal Penelitian Hasil Hutan (2012) Vol. 30, No. 3, ISSN : 0216-4329.

[22] S. Yuniningsih dan S. P. A. Anggraini, Characterization of Liquid Smoke from Coconut Shell to Be Applicated as Safe Food Preservatives for Human Health, Journal of Agriculture and Food Technology (2013) Vol. 3 No. 2, ISSN 2090-424X.

[23] W. C. Sung, M. Stone dan F. M. Sun, Analysis of Volatile Constituents of Different Temperature Rice Hulls Liquid Smoke, Chia-nan Annual Bulletin (2007) Vol. 33.

[24] Y. Chhiti dan M. Kemiha, Thermal Conversion of Biomass, Pyrolysis and Gasification : A Review, The International Journal of Engineering and Science (2013) Vol. 2m Issue 3, ISSN 2319 -1813, ISBN $2319-1805$.

[25] Z. F. Fachraniah dan Z. Rahmi, Peningkatan Kualitas Asap Cair dengan Distilasi, Journal of Science and Technology (2009) Vol.7 No. 14, ISSN 1693-248X. 